\title{
Detecção de Xanthomonas axonopodis pv. phaseoli em Sementes de Feijão em Meio de Cultura Semi Seletivo
}

\author{
Nilvanira D. Tebaldi, Ricardo M. Souza \& José C. Machado \\ Departamento de Fitopatologia, Universidade Federal de Lavras, Cx. Postal 3037, CEP 37200-000, \\ Lavras, MG, e-mail: rmagelas@ufla.br
}

Autor para correspondência: Ricardo M. Souza

TEBALDI, N.D., SOUZA, R.M. \& MACHADO, J.C. Detecção de Xanthomonas axonopodis pv. phaseoli em sementes de feijão em meio de cultura semi seletivo. Fitopatologia Brasileira 32:056-058. 2007.

\begin{abstract}
RESUMO
Para a deteç̧ão de Xanthomonas axonopodis pv. phaseoli (Xap) em extratos de sementes inteiras e moídas de feijão, naturalmente contaminadas e sadias foram utilizados os meio de cultura semi-seletivos XCP1 e MT e o não seletivo 523 de Kado \& Hesket. Os extratos de sementes foram também inoculados em folhas primárias de feijoeiro. O meio de cultura semi-seletivo XCP1 foi o mais eficiente na quantificação e detecção de Xap em extratos de sementes inteiras de feijão. Os extratos de sementes contaminadas, inoculados nas folhas primárias de feijoeiro produziram sintomas do crestamento bacteriano comum.
\end{abstract}

Palavras-chave adicionais: crestamento bacteriano comum.

\begin{abstract}
Detection of Xanthomonas axonopodis pv. phaseoli in seeds of common bean on semi-selective medium

To detect Xanthomonas axonopodis pv. phaseoli (Xap) in whole and crushed bean seed extracts, naturally contaminated and healthy bean seeds were used in the semi-selective media XCP1 and MT and in the non-selective medium 523. Seed extracts were also inoculated in the first leaves of bean plants. The semi-selective medium XCP1 was more efficient in the quantification and detection of Xap in whole bean seed extracts. Naturally contaminated seed extracts, inoculated in the first leaves of bean plants, showed the symptoms of bacterial blight.
\end{abstract}

Additional keywords: bean bacterial blight.

O crestamento bacteriano comum do feijoeiro, cujo agente etiológico é Xanthomonas axonopodis pv. phaseoli (Smith 1897) Vauterin, Hoste, Kersters \& Swinger (1995) (Xap) apresenta importância no Brasil (Rava \& Sartorato, 1994), devido à sua ampla distribuição, à capacidade de reduzir a produção de forma significativa e às dificuldades de controle. A doença ocorre em regiões de clima quente e úmido e houve expressão nos Estados de São Paulo, Rio de Janeiro, Minas Gerais, Paraná, Santa Catarina, Espírito Santo, Rio Grande do Sul e na região Centro-Oeste, principalmente na safra das águas (Bianchini et al., 2005). A bactéria pode sobreviver por períodos de até 15 anos em sementes de feijão (Neergaard, 1979), as quais constituem a principal fonte de inóculo da bactéria no campo e podem ser transportadas a longas distâncias. Os testes de detecção de Xap em sementes devem ser práticos, para assegurar a sanidade dos lotes a serem comercializados e assim evitar a ocorrência de epidemias. Inúmeras técnicas foram desenvolvidas e adaptadas com a finalidade de detectar

*Parte da Tese de Doutorado da primeira autora. Universidade Federal de Lavras. 2005. a presença de Xap em sementes de feijão, como o uso de bacteriófagos, testes sorológicos como ELISA, microscopia de imunofluorescência, imunodifusão em agar e reação em cadeia da polimerase (PCR) (Malin et al., 1983; Sheppard, 1983; Van Vuurde et al., 1983; Velásquez \& Trujillo, 1984; Maringoni et al., 1994; Audy et al., 1996). No entanto, métodos mais comuns como o plaqueamento dos extratos de sementes ou a deposição direta de sementes em meio de cultura semi-seletivo têm sido usados rotineiramente para detectar e avaliar a viabilidade de bactérias (Chang et al., 1991). O objetivo deste trabalho foi verificar a eficiência de diferentes meios de cultura semi-seletivos para a detecção de Xap em sementes de feijão, utilizando-se dois métodos de extração.

Para a extração da bactéria, as sementes inteiras foram imersas em água filtrada $(60 \mathrm{~mL}$, para cada 100 sementes) por $18 \mathrm{~h} \mathrm{a} 5{ }^{\circ} \mathrm{C}$ (Valarini, 1990) e as sementes moídas foram colocadas em sacos plásticos, quebradas por um martelo e então imersas em água filtrada por duas horas em temperatura ambiente.

Para a detecção de Xap foram usados dois meios de cultura semi-seletivos: XCP1 (10 g de peptona; $10 \mathrm{~g}$ de brometo de potássio; $0,25 \mathrm{~g}$ de cloreto de cálcio; $15 \mathrm{~g}$ de 
agar; $10 \mathrm{~g}$ de amido solúvel; $0,15 \mathrm{~mL}$ de cristal violeta e $1 \mathrm{~L}$ de água destilada; após autoclavagem foram adicionados 50 $\mathrm{mg} / \mathrm{L}$ cefalexina; $10 \mathrm{mg} / \mathrm{L}$ fluorouracil; $0,4 \mathrm{mg} / \mathrm{L}$ tobramicina; $10 \mathrm{~mL}$ de Tween 80 e $50 \mathrm{mg} / \mathrm{L}$ ciclohexamina) e MT $(0,25$ $\mathrm{g}$ de cloreto de cálcio; $10 \mathrm{~g}$ de peptona; $15 \mathrm{~g}$ de agar; 0,5 $\mathrm{g}$ de tirosina; $10 \mathrm{~g}$ de leite em pó e $1 \mathrm{~L}$ de água destilada; foram adicionados após autoclavagem $10 \mathrm{~mL}$ de Tween 80 , $80 \mathrm{mg} / \mathrm{L}$ de cefalexina, $200 \mathrm{mg} / \mathrm{L}$ de ciclohexamina e 10 $\mathrm{mg} / \mathrm{L}$ de vancomicina) (Goszczynska \& Serfontein, 1998). Foi utilizado também o meio não seletivo 523 de Kado \& Heskett (1970). Sementes sadias de feijão (cv. Carioca) e naturalmente contaminadas com Xap (cvs. Roxo, Valente e Vermelho) foram utilizadas para cada método de extração, com quatro subamostras. Dos extratos das sementes imersas em água filtrada foram feitas diluições em série $\left(10^{-1}\right.$ a $\left.10^{-4}\right) \mathrm{em}$ água filtrada esterilizada. Em seguida, $100 \mu \mathrm{L}$ das diluições foram transferidas para placas de Petri contendo os meios de cultura, utilizando-se quatro placas para cada diluição. As placas foram incubadas a $28^{\circ} \mathrm{C}$ por quatro dias e, em seguida, as unidades formadoras de colônias (UFC $\mathrm{mL}^{-1}$ ) quantificadas. Foi utilizado um delineamento experimental inteiramente ao acaso. Os dados foram transformados em $\log \mathrm{x}$ e as médias comparadas pelo teste Tukey $(\mathrm{P}<0,05)$.

Os extratos das quatro subamostras das sementes contaminadas foram inoculados pelo método de corte paralelo (dois cortes laterais), nas folhas primárias de feijoeiro, cv. Carioca, utilizando-se duas plantas de feijoeiro para cada subamostra e os sintomas observados.

As colônias de Xap foram facilmente distinguidas e identificadas seis dias após a instalação do teste. Em meio semi-seletivo XCP1, as colônias apresentaram cor amarela, mucóide, forma convexa e circundadas por um halo, devido à hidrólise do amido (Figura 1A). Em meio MT, as colônias apresentaram cor amarela, forma circular não-fluorescente, com dois halos, um deles grande e claro, devido à hidrólise de caseína, e o outro pequeno e branco, devido à lipólise do Tween 80 (Figura 1B). No meio 523 foram observadas colônias amarelas e convexas, porém de tamanho maior do que as observadas nos meios semi-seletivos (XCP1 e MT), provavelmente devido à ausência de antibióticos e fungicidas no meio (Figura 1C).

Para a quantificação de Xap em extratos de sementes de feijão (Tabela 1) houve diferença significativa entre os meios XCPI, MT e 523. Os meios semi-seletivos MT e
XCP1 recuperaram de $1 \times 10^{6}$ a $1,47 \times 10^{6} \mathrm{UFC} \mathrm{mL}^{-1}$ e o meio 523, não seletivo, $1,2 \times 10^{5} \mathrm{UFC} \mathrm{mL}^{-1}$.O meio semiseletivo XPC1, além de proporcionar a recuperação de maior número de UFC $\mathrm{mL}^{-1}$, apresenta maior facilidade no preparo, permite melhor visualização das colônias formadas, quando comparado ao meio MT, e também apresenta maior inibição do crescimento de microrganismos saprófitas. Dessa forma, o meio XCP1 pode ser considerado o mais eficiente na detecção de Xap em sementes de feijoeiro e, portanto, ser recomendado para os testes de sanidade e emissão de certificados de sementes livres de Xap, o que pode contribuir para evitar a ocorrência de epidemias de crestamento bacteriano comum no campo.

Quanto aos métodos de extração da bactéria, houve diferença significativa entre as sementes inteiras $\left(1,64 \times 10^{5}\right.$ UFC $\left.\mathrm{mL}^{-1}\right)$ e moídas $\left(2,81 \times 10^{6} \mathrm{UFC} \mathrm{mL}^{-1}\right)$ (Tabela 1$)$. Para as sementes moídas foi possível recuperar 10 vezes mais UFC $\mathrm{mL}^{-1}$, quando comparado com as sementes inteiras. No entanto, procedimentos recentes têm sugerido (Valarini, 1990; Ito et al., 1997) o uso de sementes inteiras na detecção de patógenos, pois o uso de sementes trituradas é mais trabalhoso e exige uma etapa a mais na rotina do laboratório, além da dificuldade em se pipetar o extrato, devido aos fragmentos das sementes moídas.

$\mathrm{Na}$ quantificação de UFC $\mathrm{mL}^{-1}$ houve diferença significativa entre as cvs. Roxo $\left(7,7 \times 10^{5} \mathrm{UFC} \mathrm{mL}^{-1}\right)$, Valente $\left(1,76 \times 10^{6} \mathrm{UFC} \mathrm{mL}^{-1}\right)$ e Vermelho $\left(2,15 \times 10^{4} \mathrm{UFC} \mathrm{mL}^{-1}\right)$ naturalmente contaminadas com Xap, porém, a bactéria não foi detectada na cv. Carioca (sadia).

Os extratos de sementes naturalmente contaminadas, inoculados nas folhas primárias do feijoeiro, produziram sintomas do crestamento bacteriano comum em todas as subamostras analisadas.

A utilização da PCR na detecção direta de Xap em extratos de sementes não é possível, devido à presença de substâncias inibidoras da reação nestes extratos (Schaad et al., 1997) e a utilização de kits específicos para a purificação dos extratos de sementes e posterior detecção pela PCR (Audy et al., 1996) é onerosa e requer certo período de tempo. Para os testes sorológicos há necessidade de antígenos específicos para a detecção da bactéria, além da possibilidade de reações cruzadas com outras bactérias presentes na amostra e interferência de saprófitas (Van Vuurde et al., 1991). No uso de imunofluorescência há
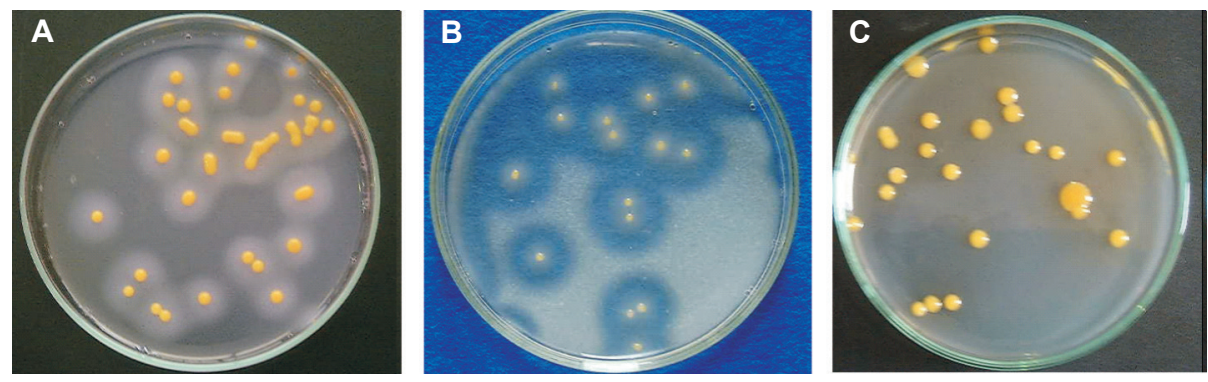

FIG. 1 - Colônias de Xanthomonas axonopodis pv. phaseoli formadas a partir de extratos de sementes de feijão naturalmente infectadas, seis dias após o plaqueamento. AB. meios de cultura semi-seletivos XCP1 e MT, respectivamente; C. meio de cultura não seletivo 523.

Fitopatol. Bras. 32(1), jan - fev 2007 
TABELA 1 - Unidades Formadoras de Colônias (UFC/mL) de Xanthomonas axonopodis pv. phaseoli a partir de extratos de sementes de feijão, em três meios de cultura, dois métodos de extração e quatro cultivares

\begin{tabular}{ll}
\hline \hline Meios de cultura & \multicolumn{1}{c}{ UFC/mL } \\
\hline XCP1 & $1,47 \times 10^{6} \mathrm{a}$ \\
MT & $1 \times 10^{6} \quad \mathrm{~b}$ \\
523 & $1,2 \times 10^{5} \mathrm{c}$
\end{tabular}

Métodos de extração

Sementes Moídas $\quad 2,81 \times 10$ a

Sementes Inteiras $1,64 \times 10^{5} \mathrm{~b}$

Cultivares

\begin{tabular}{ll} 
Carioca & $0 \quad \mathrm{~d}$ \\
Roxo & $7,7 \times 10^{5} \mathrm{~b}$ \\
Valente & $1,76 \times 10^{6} \mathrm{a}$ \\
Vermelho & $2,15 \times 10^{4} \mathrm{c}$ \\
CV $(\%)^{*}$ & 7,17 \\
\hline
\end{tabular}

*Dados transformados em $\log \mathrm{x}$.

Médias seguidas por mesma letra, não diferem significativamente entre si, pelo teste de Tukey $(\mathrm{P}<0,05)$.

necessidade do microscópio de fluorescência, não disponível em todos os laboratórios que realizam análises. A utilização de meio de cultura semi-seletivo requer pelo menos seis dias para a obtenção dos resultados, entretanto é uma técnica fácil de ser executada em exames de rotina em laboratório e não exige equipamentos sofisticados.

\section{AGRADECIMENTOS}

Pesquisa financiada pela Fundação de Apoio à Pesquisa de Minas Gerais - FAPEMIG (CAG 269/01). Os autores agradecem a Joice Aparecida Marques Santos, Embrapa Milho e Sorgo, e a Murillo Lobo Júnior, Embrapa Arroz e Feijão, pelo fornecimento de sementes de feijão. A primeira autora agradece à CAPES pela concessão da bolsa de estudos, . Os autores RMS e JCM agradecem ao Conselho Nacional de Desenvolvimento Científico e Tecnológico CNPq pela concessão de bolsa de produtividade.

\section{REFERÊNCIAS BIBLIOGRÁFICAS}

AUDY, P., BRAAT, C.E., SAINDON, G., HUANG, H.C. \& LAROCHE, A. A rapid and sensitive PCR-based assay for concurrent detection of bacteria causing common and halo blights in bean seed. Phytopathology 86:361-366. 1996.

BIANCHINI, A., MARINGONI, A.C. \& CARNEIRO, S.M.P.G.
Doenças do feijoeiro (Phaseoluls vulgaris L.). In: Kimati, H., Amorim, L., Rezende, J.A.M., Bergamin Filho, A. \& Camargo, L.E.A. (Eds.) Manual de Fitopatologia. v.2, 4 ed. São Paulo SP. Editora Ceres. 2005. pp. 333-349.

CHANG, C.J., DONALDSON, D., CROWLEY, M. \& PINNOW, D. A new semiselective medium for the isolation of Xanthomonas campestris pv. campestris from crucifer seeds. Phytopathology 81:449-453. 1991.

GOSZCZYNSKA, T. \& SERFONTEIN, J.J. Milk-Tween agar, a semi-selective medium for isolation and differentiation of Pseudomonas syringae pv. syringae, Pseudomonas syringae pv. phaseolicola and Xanthomonas axonopodis pv. phaseoli. Journal Microbiological Methods 32:65-72. 1998.

ITO, M.F., VALARINI, P.J., PATRÍCIO, F.R.A. \& SUGIMORI, M.H. Detecção de Xanthomonas campestris pv. phaseoli e fungos em sementes de feijão produzidas no estado de São Paulo. Summa Phytopathologica 23:118-121. 1997.

KADO, C.I. \& HESKETT, M.G. Selective media for isolation of Agrobacterium, Corynebacterium, Erwinia, Pseudomonas and Xanthomonas. Phytopathology 60:969-979. 1970.

MALIN, E.M., ROTH, D.A. \& BELDEN, E.L. Indirect immunofluorescent staining for detection and identification of Xanthomonas campestris pv. phaseoli in naturally infected bean seed. Plant Disease 67:645-647. 1983.

MARINGONI,A.C., KIMATI, H. \& KUROZAWA, C. Variabilidade sorológica entre isolados de Xanthomonas campestris pv. phaseoli. Summa Phytopathologica 20:164-167. 1994.

NEERGAARD, P. Seed Pathology. London. McMillan. 1979.

RAVA, C.A. \& SARTORATO, A. Crestamento bacteriano comum. In: Sartorato, A. \& Rava, C.A. (Eds.) Principais doenças do feijoeiro comum e seu controle. Brasília: EMBRAPA-SPI. 1994.

SCHAAD, N.W., BONDE, M.R. \& HATZILOUKAS, E. BIOPCR: a highly sensitive technique for detecting seed-borne fungi and bacteria. In: Hutchins, J.D. \& Reeves, J.C. (Eds.) Seed health testing progress towards the $21^{\text {st }}$ century. Cambridge. CAB International. pp. 159-164. 1997.

SHEPPARD, J.W. Detection of seed-borne bacterial blights of bean. Seed Science Technology 11:561-567. 1983.

VALARINI, P.J. Método para detecção de Xanthomonas campestris pv. phaseoli em sementes de feijão. Tese de Doutorado. Piracicaba SP. ESALQ, Universidade de São Paulo.1990.

VALTERIN, L., HOSTE, B., KERSTERS., K. \& SWINGS, J. Reclassification of Xanthomonas. International Journal of Systematic Bacteriology 45:472-489. 1995.

VAN VUURDE, J.W.L., VAN DEN BOVENKAMP, G.W. \& BIRNBAUM, Y. Immunofluorescence microscopy and enzymelinked immunosorbent assay as potencial routine tests for the detection of Pseudomonas syringae pv. phaseolicola and Xanthomonas campestris pv. phaseoli in bean seed. Seed Science and Technology 11:547-559. 1983.

VELÁSQUEZ, N.C. \& TRUJILLO, G. Comparacion de metologias para la deteccion de la infeccion de semillas de caraota (Phaseolus vulgaris L.) com la bactéria Xanthomonas campestris pv. phaseoli (Smith) Dye. Agronomia Tropical 34:29-41. 1984. 